\title{
Foreign Policy and the Internal/External Distinction: An Integrative Approach to Conceptualisation
}

\author{
Mehmet Osman ÇATI*
}

\begin{abstract}
Although it is widely accepted that one of the first steps in an investigation of an actor's foreign policy requires the precise definition of the phenomena to be explained, assessments of the state of Foreign Policy Analysis reveal that the concept 'foreign policy' is either left undefined or point out to the need to its enhancement. Therefore, this study probes into the traditional distinction between internal and external environments through the lenses of main approaches and relevant studies in the field and offers a comprehensive and integrative conceptualisation that draws attention to two interrelated aspects: (1) the overlapping nature of foreign and domestic policy that places them both in a relationship and sharing of joint place rather than absolute opposition across well-defined boundaries; and (2) the boundary drawing practices and performances that characterise the everyday life of foreign policy of states. Such a conceptualisation makes it possible to incorporate not only 'why' and 'how' questions that form the basis of the mainstream rationalistic accounts in Foreign Policy Analysis but also 'how possible' questions that are vital to reflectivist investigations.
\end{abstract}

Keywords: Foreign Policy, Foreign Policy Analysis, International Relations, Internal/External Distinction, Conceptualisation

\section{Dış Politika ve İç / Dış Ayrımı: Kavramsallaştırmaya Bütüncül Bir Yaklaşım}

\section{Öz}

Bir aktörün dış politikasının araştııılması sürecinde atılması gereken ilk adımlardan bir tanesinin soruşturulacak olan olguların itinalı bir tanımının yapılması olduğu genel bir kabul görmektedir. Buna rağmen Dış Politika Analizi alanının durumuna ilişkin değerlendirmeler "dış politika" kavramının ya tanımlanmadığına ya da kavramın tanımlanmasında iyileştirmeler yapılması gerektiğine işaret etmektedir. Bu nedenle bu çalışma geleneksel iç ve dış çevre ayırımını alandaki temel yaklaşımlar ve ilgili çalışmalar açısından irdelemekte ve birbiri ile ilişkili iki yöne dikkat çeken kapsamlı ve bütünleştirici bir kavramsallaştırma sunmaktadır: (1) dış ve iç politikanın birbirleri ile örtüşen yapıları gereğince, keskin çizgilerle belirlenmiş mutlak karşıtlık yerine her ikisinin ilişkisel ve ortak bir alanı

Asst. Prof. Dr. Muğla Sıtkı Koçman University, Faculty of Economics and Administrative Sciences, Department of Political Science and International Relations, osmancati@mu.edu.tr 
paylaşan konumları ve (2) devletlerin süregelen dış politikalarının ayrılmaz bir parçası olan sınır üreten pratik ve performansları. Böylesine bir kavramsallaştırma, Dış Politika Analizinin ana akım rasyonel yaklaşımlarının temelini oluşturan "neden" ve "nasıl" sorularının yanında, refleksif soruşturmalar için çok önemli olan "nasıl mümkün" sorusunun da içerilmesini olanaklı kılmaktadır.

Anahtar kelimeler: Dış Politika, Dış Politika Analizleri, Uluslararası İlişkiler, İç/Dış Politika Ayırımı, Kavramsallaştırma

\section{Introduction}

Since the emergence of ground-breaking works in the 1950s and 1960s, Foreign Policy Analysis has been established as an evolving and vibrant subfield of International Relations. However, although it is widely accepted that one of the first steps in an investigation of an actor's foreign policy requires the precise definition of the phenomena to be explained, assessments of the state of Foreign Policy Analysis reveal that the concept 'foreign policy' is either left undefined or point out to the need to its enhancement. Thus, what is 'foreign policy'? How can it be conceptualised? What are the problems associated with its constituent terms 'foreign' and 'policy'? How can we distinguish 'foreign policy' from 'domestic politics'?

In such an endeavour one available option is to have recourse to the traditional dichotomy between the internal and external environments. In this way state frontiers are treated as territorial as well as conceptual boundaries and 'foreign' and 'domestic' policy are separated accordingly. But the very distinction between internal and external environments has been approached in disparate ways by the existing perspectives and studies in the field. Thus, this study probes into the traditional distinction between internal and external environments through the lenses of main approaches and relevant studies in the field and offers a comprehensive and integrative conceptualisation that draws attention to two interrelated aspects: (1) the overlapping nature of foreign and domestic policy that places them both in a relationship and sharing of joint place rather than absolute opposition across well-defined boundaries; and (2) the boundary drawing practices and performances that characterise the everyday life of foreign policy of states. Such a conceptualisation makes it possible to incorporate not only 'why' and 'how' questions that form the basis of the mainstream rationalistic accounts in Foreign Policy Analysis but also 'how possible' questions that are vital to reflectivist investigations.

The following section of this paper offers a concise overview of the emergence of Foreign Policy Analysis as an evolving and vibrant subfield under the more comprehensive field of International Relations. Afterwards, a brief literature survey is undertaken to present a sample of conventional definitions of foreign policy. The next section looks into the traditional distinction between internal and external environments through the lenses of salient approaches and relevant studies in the field in order to make the case for a far-reaching conceptualisation. The conclusion 
summarises the main arguments of this paper and provides a comprehensive reconceptualisation of the term foreign policy.

\section{The Emergence of Foreign Policy Analysis}

A theory provides a systematic view of a phenomenon by presenting a series of propositions or hypotheses in order to understand or explain (Knutsen, 1992: 1). It helps determine what phenomena are important and assists in sorting out the appealing and answerable questions from the rest. One of the aims of Foreign Policy Analysis is to conceptualise and theorise the 'foreign policy' phenomena and to develop methods that will contribute to better understanding of the subject matter.

Acknowledging the importance of theory, leading scholars have made serious attempts since the early 1950s to form a theory or framework for foreign policy analysis. For example, in their pioneering work Snyder, Bruck and Sapin (1954) applied decision-making theory to foreign policy analysis and thereby initiated what became called the 'scientific' or 'comparative foreign policy' movement. Following this tradition Brecher, Steinberg and Stein (1969) provided a more complex model to 'explore state behaviour in depth and breadth'. Rosenau (1966) advanced a pre-theory that 'provides a basis for comparison in the examination of the external behaviour of various countries in various situations', while Allison (1969) enriched the field by offering Organisational Process and Bureaucratic Politics models as alternatives to the Rational Actor model and demonstrated that through their application one can arrive at three different interpretations of the same event. Subsequently, highlighting the registered progress and utilising Kuhn's concept of 'normal science, ${ }^{1}$ Rosenau (1976) announced the emergence of the study of foreign policy as a normal science by the mid-1970. Without delving into the 'Great Debate' of the 1960s between the 'traditionalists' and the 'behaviouralists' who largely differed on the methodological question of whether human behaviour is amenable to scientific enquiry as applied in the natural sciences, ${ }^{2}$ it can safely be argued that the diversity of the research on personal characteristics and cognition, perception-misperception, analogy, ideas and ideology, decision-making processes, international bargaining and conflict, nationalism, religion, gender, revolution, peace research, participation, legitimacy, human rights, ethics, health, nature of the regime and of the state, foreign economic policies and other related topics which contribute to the study of foreign policy indicates the existence and vitality of an integrative subfield under the more comprehensive field of International Relations (Cati, 2013: 23). As underscored by Kaarbo (2003: 156), current research in FPA is 'vibrant and multidimensional; it bridges gaps with adjacent disciplines, the policymaking community, and the larger field of international relations'. Yet it should be underlined

1 Rosenau states that Kuhn's formulation of a normal science allows for a field to be said to have emerged when the degree of methodological and philosophical consensus among researchers is such that their contributions are merely elaborations and refinements of each other's work. For Kuhn's original formulation of 'normal science', see Kuhn (1970).

2 For what has been called the second or the new 'great debate' following the first 'great debate' between Idealism and Realism that took place in the interwar period, see e.g., Hollis \& Smith (1991: 28-32); Little (1991: 463-478). 
that the coming of age of FPA was not due to the development of a grand unified theory capable of explaining all foreign policy behavior for all states for all the time. Such a grand theory of FPA does not exist. As articulated by Waltz $(1996,57)$ 'no one has even suggested how such a grand theory can be constructed, let alone developed one'. Progress was therefore registered by a commitment to reconcile theoretical imperatives with the complexity of the real world.

\section{The Explanandum of Foreign Policy Analysis}

Foreign policy as a concept refers to the explanandum - the phenomenon that is to be explained — of Foreign Policy Analysis. It is also referred to as the dependent variable (Carlsnaes, 2008: 99). As alluded to by Korany and Dessouki (2008: 27) an important prior task in any explanation of an actor's foreign policy requires a precise definition of the dependent variable. Although the main focus of the present study is limited to the conceptualisation of foreign policy, it needs to be emphasised that the issue at hand is also 'crucial to the choice of theoretically feasible instruments of analysis, since the nature of a given explanandum has obvious and fundamental implications for the types of explanants, that is, explanatory factors, which in principle are appropriate and fruitful' (Carlsnaes, 2002: 334). In the words of Jørgensen (2004: 50), 'conceptualisation is a precondition for theory building, in return a precondition for theory guided empirical research'.

A brief survey of the available definitions gives credence to the contention that the concept 'foreign policy' is either left undefined or fails to encompass the richness and diversity of the field due to the apparent neglect of the contributions of reflectivist approaches to the study of foreign policy.Thus, Rosenau (1966: 125, note 39), who characterises the foreign policy phenomena as 'the unwanted stepchildren' of international politics and comparative politics in one of his earlier works, does not provide a strict definition but explains that such phenomena involve governmental undertakings directed toward the external environment' or 'stated most succinctly ... are those that reflect an association between variations in the behaviour of national actors and variations in their external environments'. Korany (1986: 39), while criticising those scholars who equated a country's foreign policy solely with its foreign policy decisions, maintains that a country's foreign policy is 'a continuous, wider phenomenon, embracing general objectives, stated strategy, and a series of routine actions: trade exchanges, cultural encounters, exchanges of diplomatic notes'. Another far-reaching definition is provided by Kegley and Raymond (2010: 59) who state that foreign policy and the decision-making processes that produce it refer to 'the goals that the officials heading nation-states (and other non-state actors) seek to obtain abroad, the values that underlie those goals, and the means or instruments used to pursue them'. Moreover, White (1989: 1) draws attention to the problems surrounding the constituting terms 'foreign' and 'policy' themselves after offering a definition of foreign policy as 'that area of governmental activity which is concerned with relationships between the state and other actors, particularly other states, in the international system'. According to Braveboy-Wagner (2008: 1) foreign policy denotes 'the purposive - that is, official and intentional — actions and behaviour of states targeted toward external state as well as non-state actors'. Warner and Walker (2011:114) define foreign 
policy as the 'formal policies of a state which affect various military, economic, humanitarian, social, and cultural dimensions of its relations with other states and non-state actors. Finally, for Petriĉ (2013:1) foreign policy is an 'activity of the state with which it fulfils its aims and interests within the international arena.

\section{The Internal/External Distinction: An Explorative Review}

On the basis of our sample of definitions or elaborations it appears that recognising the problems associated with the constituent terms 'foreign' and 'policy' can be a step forward towards enhancing our understanding of the explanandum of foreign policy analysis. Thus, can we clearly distinguish 'foreign' from 'domestic' policy? In this respect, what are the insights that can be drawn from existing approaches and studies? In such an endeavour, one available option is to rely on the conventional dichotomy between 'internal' and 'external' environments. In this way state frontiers are taken not only as territorial but also as conceptual variables and 'foreign' and 'domestic' policy is separated accordingly, while the state is viewed as 'the gatekeeper between intra-societal and extra-societal flows of action' (Nettle, 1968: 564).

Although classical Realism rests on a neat distinction between domestic and foreign affairs or internal and external environments (see e.g., Vasquez, 1997: 899; Brown, 2012: 859), one of its principal formulators Morgenthau has recognised the possibility of such a breakdown. The following is his portrayal of such an instance:

An underdeveloped nation that could increase in a spectacular fashion the health, literacy, and the standard of living of its people would thereby have achieved a considerable increase in its power in other underdeveloped regions of the world.

At this point... the traditional distinction between foreign and domestic policies tends to breakdown. One might almost be tempted to say that there are no longer any purely domestic affairs, for whatever a nation does or does not do is held for or against it as a reflection of its political philosophy, system of government, and way of life (Morgenthau, 1993: 165).

Moreover, with its emphasis on anarchy as the principal organising principle of the international system and hierarchy as that of domestic political systems, neo-Realism rests on a sharp distinction between internal and external affairs. ${ }^{3}$ Accordingly, while the international realm is distinguished by the lack of an overarching central authority, political actors stand in relationships of authority and subordination in domestic politics (Waltz, 1979: 88-97). In this view which 'privileges the autonomous nature of the anarchic international system and focuses on the pressures that it places on every nation-state', the foreign policies of states are best explained 'as a rational response to these external pressures' (Kapstein, 1995: 754).

3 The seminal example of neo-Realism is Waltz, 1979. For select post-Cold War restatements see e.g., Jervis (1998); Waltz (2000); Mearshemier (2001). 
However, Buzan, who has profoundly contributed to neo-realist scholarship, acknowledges that the distinction between internal and external affairs may not hold in some cases. In his discussion of the relationship between individual and national security, for example, Buzan (1991:53) points out that citizens of a state could act or be accused of acting as a fifth column in support of some other state. He adds that 'where this happens, neat distinctions between citizens and foreigners, state and government, and domestic and international policy, begin to breakdown'.

Although neo-Realism as espoused by Waltz privileges systemic imperatives and plays down the significance of unit-level variables, the proponents of neoclassical Realism endeavour to integrate domestic politics, norms and ideas into their analyses to explain foreign policy behaviour of states. More precisely, drawing upon neo-Realism they emphasise the importance of the anarchic international environment and suggest that international systemic pressures are the most important cause behind the foreign policy behaviour of particular states, but only through the mediating effect of unit-level variables' (Dueck, 2009: 141). Hence they retain the traditional distinction between internal and external environments but they strive to bridge the gap between the two in their analyses. Their sub-systemic variables include domestic coalition making and ideological myth-making, state power, political influence of interest groups, domestic politics of national identity, elite perceptions, and internal extraction capacity (e.g., Snyder, 1991; Zakaria, 1998; Mearsheimer \& Walt, 2007; Sterling-Folker, 2009).

Snyder, in a representative example, links the pattern of late development to overexpansion which he defines as self-encirclement by belligerent behaviour and/or persistent expansion into the periphery beyond the point where costs begin to exceed benefits (Snyder, 1991: 6 and 305). In his attempt to explain the frequent occurrence of great power overexpansion, Snyder considers variation in the type of domestic political structure - unitary, cartelised and democratic - and the timing of industrialisation - early, late, 'late late' industrialisation — as crucial. The empirical validity of his theory is tested by the examination of five cases of great power politics: Great Britain in the Victorian period, Germany and Japan in the pre-World War II era, and the United States and the Soviet Union during the Cold War. The whole argument is succinctly summarised as follows:

The experience of the industrialised great powers suggests that coalition politics and ideology offer the single best explanation for the strategic ideas that contribute to overexpansion. Though the international factors stressed by Realism also play an important role, their effects are skewed by domestic coalition making and ideological myth-making (Snyder, 1991: 32).

Neoclassical Realists have also criticised 'the narrowing of intellectual focus in the field of grand strategy' that results from the earlier Realists' emphasis on the external environment and have sought to broaden their purview by the inclusion of domestic politics, economics and ideas as intervening variables (Rosecrance and Stein, 1993: 4). Hence, Rosecrance and Stein (1993: 5) contend that 'grand strategic assessments focusing only on narrow constituents of realism 
- material power, changes in its distribution and external threat - are radically incomplete and do not account for what nations actually do'. Instead, they assign, together with other contributors to their volume, a vital role in the choice of a grand strategy to 'domestic groups, social ideas, the character of constitutions, economic constraints (sometimes expressed through international interdependence), historical social tendencies and domestic political pressures'.

In another neoclassical Realist work, Lobell (2003: 3) takes a view similar to Rosecrance and Stein as he asserts that 'grand strategy is not only military, but also fiscal and political in nature'. As a result, in his endeavour to integrate the Realist current that 'accentuates systemic pressures as determining but ignores the influence of domestic politics on a state's grand strategy' with domestic political approaches that 'grant domestic coalitions primacy but neglect the influence of international politics', Lobell arrives at the conclusion that a declining hegemon's grand strategy is guided by its international commercial environment and the domestic coalitional outcome bell, 2003: 8 and 19). strategic ideas as an intervening variable to describe 'how the structural pressures of power in the international system are translated into foreign policy outcomes', Kitchen (2010: 119 and 136) asserts that 'the insights of neoclassical realism fit well with a process of grand strategy formation that is plural, constrained by systemic imperatives and yet determined by ideational factors at unit level'.

In short, while almost all upholders of different types of Realism tend to base their works on a neat dichotomy between internal and external affairs or environments, some depart from the rest by conceding the possibility of a breakdown of the assumed distinction at least in some cases and others endeavour to integrate the two environments in their explanations.

Conversely, either the erosion of the distinction, or the notion of non-distinction, is at the centre of neo-Liberalism and (neo-Marxist) Structuralism, the other two Cold War era mainstream approaches to the study of international relations. Thus, while neo-Liberalism makes its case for the erosion of the distinction from the point of view of the advanced capitalist states by pointing towards their increasing 'interdependence', Structuralism rejects the distinction from the perspective of the less-developed countries by pointing to the mechanisms that perpetuate their 'underdevelopment' or 'dependent development'.

For example, in the 'complex interdependence' model developed by Keohane and Nye (1989), the existence of multiple channels of formal and informal contacts among societies, the absence of hierarchy among issues of a military and non-military nature, and the diminishing salience of force as an instrument of policy among industrialised pluralist countries lead to the breakdown of the distinction between domestic and international politics. As the authors who are considered the founding fathers of neo-Liberalism succinctly put it: 'as the complexity of actors and issues in world politics increases, the utility of force declines and the line between domestic policy and foreign policy become blurred' (Keohane and Nye, 1989: 32).

Neo-Marxist Structural arguments, however, flow from key assumptions concerning the unequal nature of exchange in the global economy and consequent division of the world into 
centre (core) and periphery. Since the world capitalist system embodies structural domination of the core and the dependence of the periphery, it is contended that the balance of benefits from international processes of exchange is biased towards the centre. It is also argued that the structures of domination and dependence produce political and economic elites whose interests are in harmony with those of multinational corporations and core country ruling classes. The latter, however, are not seen as external to the periphery but intrinsic to the world capitalist system. As elaborated by Sunkel (1972: 519):

Foreign factors are seen not as external but as intrinsic to the system, with manifold and sometimes hidden or subtle political, financial, economic, technical and cultural effects inside the underdeveloped country. These contribute significantly to shaping the nature and operation of the economy, society and polity, a kind of 'fifth column' as it were.

Moreover, one key feature of the contemporary literature on 'Empire', which has been animated by Structural thinking, is its inclination to analyse the social world as a totality and its reliance on unbounded frontiers. For instance, in one of the landmarks of this literature, Hardt and Negri (2000) present the notion of 'Empire' as a new form of sovereignty and argue that this 'new logic and structure of rule' has emerged along with the globalisation of economic and cultural exchanges. Accordingly, in contrast to 'imperialism' which they see as an extension of the sovereignty of European powers beyond their own borders, 'Empire' refers to 'a decentralised and deterritorializing apparatus of rule that progressively incorporates the entire global realm within its open, expanding frontiers' (pp. xi-xii, emphasis in original). As Barkawi and Laffey (2002, 116) observe in their critical review, Empire offers 'a "total" analysis of world politics past and present. Core and periphery, North and South, East and West, inside and outside are treated as part of a single, increasingly global formation, structured and produced by imperial relations of diverse kinds'.

On the other hand the epistemological, methodological, ontological and normative assumptions of the mainstream theories have been challenged in varying degrees by different approaches that have risen to prominence since the 1980s. ${ }^{4}$

Of these, Constructivism has become one of the major schools of thought within IR. While Nicholas Onuf has coined the term 'constructivism' to describe theories that emphasise the socially constructed nature of international relations (Kubálková, Onuf and Kowert, 1998: 4), Alexander Wendt's writings are generally accepted as the most influential formative contribution. In Wendt's (1995:81) view, the social construction of international politics is an analysis of 'how processes of interaction produce and reproduce the social structures-cooperative or conflictual-that shape actors' identities and interests and the significance of their material contexts'. As Wendt

$4 \quad$ While the three mainstream schools of thought are placed in the categories of rationalistic accounts or explanatory or materialist theories, the challenges are categorised as constitutive theories or reflective accounts. In this view, the main difference is between those approaches that offer explanations of 'reality' and those that see theory as constitutive of that 'reality'. (Smith, 1995: 24-30). 
maintains in his central work Social Theory of International Politics (1999: 1), the two basic tenets of Constructivism are '(1) that the structures of human association are determined primarily by shared ideas rather than material forces, and (2) that the identities and interests of purposive actors are constructed by these shared ideas rather than given by nature. The Constructivists emphasise the importance of normative and ideational structures because these are thought to shape the social identities of social and political actors and influence their actions. Whereas neoRealists define the structure of the international system as the distribution of material capabilities of states under anarchy, and the Marxists stress the material structure of the capitalist world economy, Constructivists attribute structural characteristics to shared ideas, beliefs and values. In the words of Wendt (1999: 5), they envisage the structure of the international system as a distribution of ideas because they have an idealist ontology'

Despite having ontological differences, Wendt shares some key premises of Waltzian neo-Realism such as the existence of anarchy and the centrality of states in the international system. However, Wendt (1992) portrays anarchy in cultural rather than materialist terms as he upholds that anarchy is socially constructed among states: 'anarchy is what states make of it'. Moreover, in his attempt to develop a systemic theory, Wendt focuses on the interactions between states in the international system. In this endeavour, he adopts the state as the primary unit of analysis and brackets the unit level processes. Wendt (1999: 9) justifies his 'states systemic project' on the grounds that 'since states are the dominant form of subjectivity in contemporary world politics this means that they should be the primary unit of analysis for thinking about the global regulation of violence'. Therefore, according to Wendt (1999: 13), 'the possibility of systems theory of whatever kind, assumes that the domestic or unit level and the systemic levels of analysis can be separated.

It must be added that whilst Wendt can be taken as a leading representative of Constructivism's systemic variant since he adopts the traditional distinction between internal and external environments and lays emphasis on the latter, a holistic strand approaches these realms as two faces of a single global order and investigates the mutually constitutive relationship between this order and the state. As Price and Reus-Smit (1998: 269) explain, while the existence of domestic and international realms is not denied, the division is rather seen 'as a unique historical construct, the chief consequence and characteristic of a distinctly modern political order built around territorial sovereign states'.

Whereas adherents of Constructivism tend to uphold the assumed distinction between internal and external environments, other reflective accounts generally argue against maintaining such a distinction. In a nutshell, these include critical theory whose commitment to emancipation transcends territorial boundaries (e.g., Cox, 1981; Linklater, 1992); postmodernism which rejects the traditional distinction 'from the vantage point of the marginalised, the silenced, the omitted, those whose lives, cultures, and histories have for so long been read out of the power politics narrative' (George, 1994: 212); and feminist approaches that expose the gender blindness of IR and attempt to reveal its biases irrespective of any 'established' boundaries. Feminism's objection to the traditional domestic-international distinction as a basis to establish disciplinary boundaries 
is unambiguously expressed by True (2005: 223): 'For feminist analysts, the independence of domestic politics from international politics and the separation of public from private spheres cannot be the basis for a disciplinary boundary, since anarchy outside typically supports gender hierarchy at home and vice versa'.

One of the most sustained and intense critique of the conventional understanding of foreign policy as governmental undertakings oriented towards the external world has been undertaken by the adherents of poststructuralism whose main concerns include, as Walker (1993: 25) puts it, to 'destabilise seemingly opposed categories by showing how they are at once mutually constitutive and yet always in the process of dissolving into each other'. For example, problematising the inside and outside dichotomy and emphasising the significance of its construction, Doty presents the immigration debates of Great Britain in the period from 1948 to 1981 as constitutive of an internal/external boundary that might contain a political community with some sense of a shared national identity. As she maintains:

the inside/outside boundary is a function of a state's discursive authority, that is, its ability, in the face of ambiguity and uncertainty, to impose fixed and stable meanings about who belongs and who does not belong to the nation, and thereby to distinguish a specific political community - the inside - from all others - the outside (Doty, 1996: 122).

Hence, Doty suggests that rather than being chiefly about relations between different state units, statecraft is also about the construction and the reconstruction of the units themselves.

In another stimulating example of a poststructuralist account, Campbell (1992: 42 and 76) both challenges the conventional understanding of foreign policy 'as a state-centric phenomenon in which there is an internally mediated response to an externally induced situation of ideological, military, and economic threats', and complements it with 'the forms of "foreign policy" which have operated in terms of the paradigm of sovereignty and constituted identity through time and across space'. Drawing on Ashley's (1989: 270) problematization of the principle of state sovereignty that makes it possible to say with any clarity what states, domestic societies, their boundaries, and their historical problems and dangers are', Campbell (1992: 72) presents sovereignty and anarchy as 'replicable concepts that are pivotal for the construction in various realms of mutually reinforcing dichotomies such as subject/object, inside/outside, self/other, rational/irrational, true/false, order/disorder, and so on'.

This poststructuralist reading of the principle of sovereignty shifts the focus towards the constitution of identities. More particularly for our purposes, it directs attention to the role of foreign policy in the reproduction of identity at the level of the state, the inscription of boundaries and the attendant political practices through which certain actors and events are made 'foreign'. As explained by Campbell (1992: 75): 
State identity can be understood as the outcome of exclusionary practices in which resistant elements to a secure identity on the "inside" are linked through a discourse of "danger" with threats identified and located on the "outside". The outcome of this is that boundaries are constructed, spaces demarcated, standards of legitimacy incorporated, interpretations of history privileged, and alternatives marginalised. Foreign policy (conventionally understood as the external orientation of pre-established states with secure identities) is thus to be re-theorised as one of the boundary-producing practices central to the production and reproduction of the identity in whose name it operates.

The consequence of this poststructuralist argument is that it underlines a dimension of foreign policy that is generally ignored by its conventional understandings that tend to focus on relations between states which take place across ahistorical and pre-given boundaries. Therefore, rather than starting from a given subject of the state, foreign policy '(re)constructs the identity of the state through representing something or someone else as "foreign" and thereby also setting out what counts as "not foreign", or in other words setting out the attributes of the "self" (Diez, 2014: 33). Thus foreign policy may not only be taken as a medium for the expression of state identity but may also become a medium for the construction and reconstruction of state identities (Kirdiş, 2015). This neglected dimension relates to the discourses or representations of dangers, threats and fears that are used to construct and secure the boundaries of a state's identity. It also involves the exclusionary practices that assume a disciplining function inside the state, by representing dissident elements as 'alien', 'foreign' or 'subversive' and linking them to external threats. In this broader perspective, foreign policy may include questions of a domestic government agency that reviews immigration applications for their eligibility for naturalisation (Campbell, 1992), a moviescene and report in a newspaper (Balc1, 2007), or European Union discourses on enlargement (Aydın-Düzgit, 2012).

Additionally, the traditional distinction between international and domestic politics has been challenged from the comparativist's perspective by Gourevitch in a stimulating article which paved the way for the emergence of a 'second-image-reversed' 5 approach. Although in the essay he focuses on the international causes of domestic structures and regimes, Gourevitch's broader argument rests on the 'hopelessly interpenetration' of foreign and domestic politics. As he succinctly put it:

The international system is not only a consequence of domestic politics and structures but a cause of them. Economic relations and military pressures constrain an entire range of domestic behaviours, from policy decisions to political forms. International relations and domestic politics are therefore so interrelated that they should be analysed simultaneously, as wholes (Gourevitch, 1978: 911).

5 The original distinction between the 'first image' (i.e. the nature and behaviour of man), the 'second image' (i.e. the nature of the state and domestic society), and the 'third image' (i.e. the nature of the international system of states) is made in Waltz (1959). 
Subsequently, Putnam (1993) pointed out the limitations of the existing literature in accounting for what he described as the puzzling entanglements of domestic and international politics. So he proposed a conceptual framework that provides for the simultaneous treatment of international and domestic factors at least in international bargaining situations which require the conclusion of an agreement and its subsequent ratification. In Putnam's 'two-level games' model, central decision makers appear in two tables, one representing domestic politics and the other international negotiations. The novelty, despite the metaphoric separation, is that statesmen endeavour to reconcile domestic and international imperatives simultaneously. This view stands in sharp contrast to the neo-Realist orthodox perspective which takes the state 'as a billiard ball whose internal components are impervious to foreign pressures' (Krasner, 1978: 55) and contends that domestic politics should not be allowed to interfere in foreign policy decision making because of the stakes (Rathbun, 2008: 304).

Besides, the 'ambiguity' or 'obfuscation' or 'worldwide blurring' or the 'erosion' of the foreigndomestic distinction is a recurrent theme in the writings of Rosenau, one of the most ingenious and prolific contributors to the study of foreign policy and international relations. His attempts to give conceptual and theoretical expression to the theme is all apparent in, for example, his work on 'linkage politics' (Rosenau, 1969). In a further elaboration in a more recent study, Rosenau (1997: 4-5) asserts that the rapidity and complexity of enormous transformative changes that are unfolding on a global scale have created 'a new and wide political space', which he designates as the 'Frontier'. Thus the Frontier is offered 'as a widening field of action, as the space in which world affairs unfold, as the arena in which domestic and foreign issues converge, intermesh, or otherwise become indistinguishable within a seamless web'. The endeavour to meet the challenge of achieving governance along the turbulent Frontier, in turn, leads Rosenau (1997: 29-32) to develop a new worldview whose key constituents include the remoulding of the relevance of territoriality and underlining the porosity of boundaries separating domestic and foreign affairs.

It needs to be added that a majority of students of the global South have found the traditional distinction between internal and external environments problematic. For instance, for Clapham two intertwined legacies of the colonial period, the dependence of Third World states on, and their penetration by, external interests are at the root of this problematic:

Any chart of the flow of economic transactions, or still more sensitively of armaments, demonstrates the umbilical cord through which the third world is bound to the industrial states. Less easily measured but equally significant, is the way in which these transactions create and sustain domestic political groups whose interests tie them to the outside. In this sense, the traditional dichotomy which separates domestic from external politics and policy simply does not exist (Clapham, 1985: 113).

Both Dunn (2001) and Maclean (2001), on the other hand, emphasise the importance of international financial institutions, namely the International Monetary Fund (IMF) and the 
World Bank, in African international relations as a major factor that either increasingly blur or obscure the assumed distinction between domestic and international spheres.

Finally, for President of International Crisis Group Guéhenno (2015: 4) the distinction between internal and external affairs is blurred because 'domestic fragility whether in industrialised Ukraine or the developing Democratic Republic of Congo or South Sudan creates opportunities for foreign meddling.

Thus the traditional distinction between internal and external environments is helpful as a starting point but arguably more to demonstrate the problematic nature of the separation of domestic from foreign policy. Therefore, to adopt Owen's (2001: 242) observation on the formalinformal sector dichotomy in an economy, foreign and domestic policy are better understood as a pair in 'both a relationship and a sharing of joint space rather than an absolute opposition across well-defined boundaries'. In other words, this study proposes that domestic and foreign policy are better seen 'as distinctions along a continuum' (Wurfel and Burton, 1990: 5) more disposed to overlap than to diverge.

As in the case of 'foreign', the meaning of the term 'policy' is not without its ambiguities. In its two main usages it can either connote a plan of action, statement of aims and ideals, or pragmatic responses to situations as and when they arise. The answer given by Neville Chamberlain to a Labour critic in the (British) House of Commons in the interwar period is illustrative of different attitudes towards the term:

What does the hon. Member mean by foreign policy? You can lay down sound and general propositions. You can say that your foreign policy is to maintain peace; you can say that it is to protect British interests, you can say that it is to use your influence, such as it is, on behalf of the right against wrong, as far as you can tell the right from wrong. You can lay down all these general principles but that is not a policy. Surely, if you are to have policy you must take the particular situations and consider what action or inaction is suitable for those particular situations. That is what I myself mean by policy, and it is quite clear that as the situations and conditions in foreign affairs continually change from day to day, your policy can not be stated once and for all, if it is to be applicable to every situation that arises (Chamberlain, The Struggle for Peace: 33 as quoted in Carr, 1991: 19-20).

Mirroring its use in practice some scholars use foreign policy to refer to the principles, values or initiatives which guide a political unit's general orientation towards its international environment. Others use the term to refer to the totality of day-to-day responses to events that concern relations between states and various actors and objects in their international environments (e.g., White, 1989: 6; Jørgensen, 2004: 46-48). As we have already seen, poststructuralists assert that the term should include the boundary drawing performances practices and performances characterise the 
everyday life states. What needs to be added is that an actor's foreign policy, viewed as a dynamic process, involves all three elements.

Thus this study views foreign policy, as a continuous, broad phenomenon embracing not only general statements, long-term objectives and decision-making processes, but also the totality of everyday actions and responses, such as trade exchanges, various types of agreements, the exchange of diplomatic notes as well as the discourses, representations and exclusionary practices used to construct and secure the boundaries of the identity of a political unit.

\section{Conclusion}

This study views Foreign Policy Analysis as an evolving and vibrant subfield of International Relations and argues that one of the first steps in an investigation of an actor's foreign policy requires the conceptualisation of the phenomena to be explained. It is also contended that an attempt at conceptualisation requires the recognition of the ambiguities associated with 'foreign' and 'policy', the constituent terms of the explanandum.

An extensive but admittedly non-exhaustive review of the existing perspectives and relevant studies undertaken in this work suggests that the traditional distinction between internal and external environments is helpful as a starting point but arguably more to demonstrate the problematic nature of the separation of domestic from foreign policy. Hence, it is argued that domestic and foreign policy are better understood as a pair in both a relationship and a sharing of joint space rather than an absolute opposition across well-defined boundaries. In this sense, state frontiers are not simply taken as conceptual variables but their designation as boundaries between secure insides and an anarchic outside are regarded as objects of investigation. Foreign Policy Analysis is not only about the external orientation of pre-established state or non-state actors but also about the very construction of boundaries of self and other, inside and outside, domestic and foreign. The present study also maintains that the explanandum's constituent term policy involves both a political unit's general orientation and, the totality of its everyday practices, performances and responses.

Therefore, this study offers a conceptualisation of foreign policy as a continuous, broad phenomenon embracing general statements, long-term objectives, decision-making processes, routine actions and responses of a political unit towards other actors in its external environment as well as its discourses and representations that construct the boundaries of its identity and serve to discipline its dissident elements. This comprehensive and integrative conceptualisation makes it possible to incorporate not only 'why' and 'how' questions that form the basis of the mainstream rationalistic accounts in Foreign Policy Analysis but also 'how possible' questions that are vital to reflectivist investigations. 


\section{References}

Allison, G. (1969) “Conceptual Models and the Cuban Missile Crisis”, American Political Science Review, 63/3: 689-718.

Ashley, R. K. (1989) “Living on Borderlines: Man, Structuralism, and War”, in Der Derian J. and M. J. Shapiro (eds.), International/intertextual Relations: Postmodern Readings of World Politics, New York: Lexington Books.

Aydın-Düzgit, S. (2012) Constructions of European Identity: Debates and Discourses on Turkey and the EU, New York: Palgrave.

Balcı, A. (2007) “Diskors ve Pratik Olarak Dış Politika”, Uluslararası İlişkiler, Vol. 4/15: 67-87.

Barkawi, T., M. Laffey (2002) "Retrieving the Imperial: Empire and International Relations', Millenium: Journal of International Studies, 31/1: 109-127.

Braveboy-Wagner, J. A. (2008) Small States in Global Affairs. The Foreign Policies of the Caribbean Community (CARICOM), New York: Palgrave Macmillan.

Brecher, M., Steinberg, B. \& Stein, J. (1969) “A Framework for Research on Foreign Policy Behavior", Journal of Conflict Resolution, 13/1: 75-101.

Brown, C. (2012) “Realism: Rational or Reasonable?”, International Affairs, 88/4: 867-877.

Buzan, B. (1991) People, States and Fear, New York: Harvester Wheatsheaf.

Campbell, D. (1992) Writing Security: United States Foreign Policy and the Politics of Identity, Minneapolis: University of Minnesota Press.

Carlsnaes, W. (2002) "Foreign Policy" in Carlsnaes W., T. Risse and B. A. Simmons (eds.), Handbook of International Relations, London: Sage Publications.

Carlsnaes, W. (2008) "Actors, Structures, and Foreign Policy Analysis" in Smith S., A. Hadfield and T. Dunne (eds.), Foreign Policy: Theories, Actors, Cases, Oxford: Oxford University Press.

Cati, M. O. (2013) The Political Economy of Syrian Foreign Policy: 1949-1963, Unpublished Ph.D. Dissertation, SOAS, University of London.

Chamberlain, N. (1937) The Struggle for Peace, as quoted in Carr E. H. (1991) The Twenty Years' Crisis 1919-1939, London: Papermac.

Clapham, C. (1985) Third World Politics, London: Routledge.

Cox, R. W. (1981) "Social Forces, States and World Orders: Beyond International Relations Theory", Millennium: Journal of International Studies, 10/2: 126-55. Reprinted with a postscript in Keohane, R. O. (ed.), (1986) Neorealism and Its Critics, New York: Columbia University Press.

Diez, T. (2014) "Speaking Europe, Drawing Boundaries: Reflections on the Role of Discourse in EU Foreign Policy and Identity", in Morin J.-F. and Carta C. (eds.), EU Foreign Policy through the Lens of Discourse Analysis: Making Sense of Diversity, (Surrey: Ashgate).

Doty, R. L. (1996) "Sovereignty and the Nation: Constructing the Boundaries of National Identity", in Biersteker, T. J. and C. Weber, State Sovereignty as Social Construct, Cambridge: Cambridge University Press.

Dueck, C. (2009) "Neoclassical Realism and the National Interest: Presidents, Domestic Politics and Major Military Interventions", in Lobell S. E., N. M. Ripsman and J. W. Taliaferro (eds.), Neoclassical Realism, the State, and Foreign Policy, Cambridge: Cambridge University Press.

Dunn, K. C. (2001) "MadLib \#32: The (blank) African state: Rethinking the Sovereign State in International Relations theory', in Dunn K. C. and T. M. Shaw (eds.), Africa's Challenge to International Relations Theory, New York: Palgrave Macmillan. 
George, J. (1994) Discourses of Global Politics: A Critical (Re)introduction to International Relations, Boulder, Colorado: Lynne Rienner Publishers.

Gourevitch, P. (1978) “The Second Image Reversed: The International Sources of Domestic Politics", International Organisation, 32/4: 881-912.

Guéhenno, J. M. (6 Feb 2015) “The Long Road to Peace”, available at https://www.crisisgroup.org/global/ long-road-peace [Accessed on 5 May 2016].

Hardt, M. and A. Negri (2000) Empire, Cambridge, MA: Harvard University Press.

Hollis, M. and Smith S., (1991) Explaining and Understanding International Relations, Oxford: Clarendon Press.

Jørgensen, K. E. (2004) "European Foreign Policy: Conceptualising the Domain" in Carlsnaes W., H. Sjursen and B. White (eds.), Contemporary European Foreign Policy, London: Sage Publishers.

Kaarbo, J. (2003) "Foreign Policy Analysis in the Twenty-first Century: Back to Comparison, Forward to Identity and Ideas", International Studies Review, 5/2: 156-163.

Kapstein, E. (1995) “Is Realism Dead? Domestic Sources of International Politics”, International Organization, 49/4: 751-774.

Kegley, C. W. Jr. and G. A. Raymond (2010) The Global Future: A Brief Introduction to World Politics, (Third edition), Boston: Wadsworth Cengage Learning.

Keohane, R. O. and J. S. Nye (1989) Power and Interdependence: World Politics in Transition, (Second Edition), Boston, MA: Scott, Foresman and Company.

Kirdiş, Esen (2015) “The Role of Foreign Policy in Constructing the Party Identity of the Turkish Justice and Development Party (AKP)", Turkish Studies, 16/2: 178-194.

Korany, B. (1986) "Foreign Policy Decision-making Theory and the Third World: Payoffs and Pitfalls", in Korany B. (ed.), How Foreign Policy Decisions are made in the Third World, London, Westview Press.

Korany, B. and A. E. H. Dessouki (eds.), (2008) Foreign Policies of Arab States: The Challenge of Globalization, Cairo EGY: American University in Cairo Press.

Knutsen, T. L. (1992) A History of International Relations Theory, Manchester: Manchester University Press.

Krasner, S. D. (1978) Defending the National Interest: Raw Materials Investments and US Foreign Policy, Princeton: Princeton University Press.

Kubálková, V., N. Onuf and P. Kowert (1998) “Constructing Constructivism” in Kubálková, V., N. Onuf and P. Kowert (eds.), International Relations in a Constructed World, Armonk, NY: M. E. Sharpe.

Kuhn, T. S. (1970) The Structure of Scientific Revolutions, Chicago: University of Chicago Press.

Linklater, A. (1992) “The Question of the Next Stage in International Relations Theory: A Critical-theoretical Point of View”, Millennium: Journal of International Studies, 21/1: 77-98.

Little, R. (1991) "International Relations and the Methodological Turn", Political Studies, 39: 463-478.

Lobell, S. E. (2003) The Challenge of Hegemony: Grand Strategy, Trade, and Domestic Politic,. Ann Arbor, MI, USA: Michigan University Press.

MacLean, S. J. (2001) "Challenging Westphalia: Issues of Sovereignty and Identity in Southern Africa" in Dunn, K. C. and T. M. Shaw (eds.), Africa's Challenge to International Relations Theory, New York: Palgrave Macmillan.

Mearsheimer, J. J. and S. M. Walt (2007) The Israel Lobby and the U.S. Foreign Policy, New York: Farrar, Straus and Giroud.

Morgenthau, H. J. (1962) “A Political Theory of Foreign Aid”, American Political Science Review, 56/2: 301309. 
Morgenthau, H. J. (1993) Politics among Nations: The Struggle for Power and Peace, Revised by K. W. Thomson, New York: McGraw-Hill.

Nettle, J. P. (1968) “The State as a Conceptual Variable”, World Politics, 20/4: 559-592.

Owen, R. (2001), “The Middle Eastern State: Repositioning not Retreat?”, in Hakimian, H. and Z. Moshaver (eds.), The State and Global Change: The Political Economy of Transition in the Middle East and North Africa, Surrey: Curzon.

Petriĉ, E. (2013) Foreign Policy: From Conception to Diplomatic Practice, Leiden and Boston: Martinus Nijhoff Publishers.

Putnam, R. D. (1988) “Diplomacy and Domestic Politics: The Logic of Two-level Games", International Organisation, 42: 427-460 as reprinted in Evans, P. B., H. K. Jacobson and R. D. Putnam (eds.), (1993) Double Edged Diplomacy, Berkeley and Los Angeles: University of California Press.

Price, R. and C. Reus-Smit (1998) "Dangerous Liaisons: Critical International Theory and Constructivism, European Journal of International Relations, 4/3: 259-294.

Rathbun, B. (2008) "A Rose by Any Other Name: Neoclassical Realism as the Logical and Necessary Extension of Structural Realism”, Security Studies, 17/2: 294-321.

Rose, G. (1998) “Neoclassical Realism and Theories of Foreign Policy”, World Politics, 51/1: 144-172.

Rosecrance, R. and A. A. Stein (1993) "Beyond Realism: The Study of Grand Strategy", in Rosecrance, R. and A. A. Stein (eds.), The Domestic Bases of Grand Strategy, Ithaca, N.Y.:

Rosenau, J. N. (ed.) (1969) Linkage Politics: Essays on the Convergence of National and International Systems, (New York: The Free Press). As reprinted in Rosenau, J. N. (1980) The Scientific Study of Foreign Policy, Revised and Enlarged Edition, London: Francis Pinter.

Rosenau, J. N. (ed.) (1976) In search of global patterns, New York: Free Press.

Rosenau, J. N. (1997) Along the Domestic-foreign Frontier: Exploring Governance in a Turbulent World, Cambridge: Cambridge University Press.

Smith, S. (1995) “The Self-images of a Discipline: A Genealogy of International Relations Theory”, in Booth, K. and S. Smith (eds.), International Relations Theory Today, Cambridge: Polity Press.

Snyder, J. (1991) Myths of Empire: Domestic Politics and International Ambition, Ithaca and London: Cornell University Press.

Snyder, R. C., H. W. Bruck, and B. Sapin (1954) Decision-making as an Approach to the Study of International Politics, N.J.: Princeton University.

Sterling-Folker, J. (2009) “Neoclassical Realism and Identity: Peril despite Profits across the Taiwan Strait”, in Lobell, S. E., N. M. Ripsman and J. W. Taliaferro (eds.), Neoclassical Realism, the State, and Foreign Policy, Cambridge, Cambridge University Press.

Sunkel, O. (1972) “Big Business and 'Dependencia”, Foreign Affairs, 50: 517-531.

True, J. (2005) “Feminism”, in Burchill, S., A. Linklater, R. Devetak, J. Donnelly, M. Paterson, C. Reus-Smit and J. True (eds.), Theories of International Relations, New York: Palgrave Macmillan.

Vasquez, J. (1997) "The Realist Paradigm and Degenerative versus Progressive Research Programs: An Appraisal of Neotraditional Research on Waltz's Balancing Proposition", American Political Science Review, 9/4: 899-912.

Walker, R. B. J. (1993) Inside/outside: International Relations as a Political Theory, Cambridge: Cambridge University Press.

Waltz, K. N. (1959) Man, the State, and War, New York: Columbia University Press.

Waltz, K. N. (1979) Theory of International Politics, New York: McGraw-Hill. 
Waltz, K. N. (1996) "International Politics is not Foreign Policy", Security Studies, 6/1: 54-57.

Warner, C. M. and S. G. Walker (2011) "Thinking about the Role of Religion in Foreign Policy Analysis: A Framework for Analysis", Foreign Policy Analysis, 7/1: 113-135.

Wendt, A. (1992) "Anarchy is What States Make of It: The Social Construction of Power Politics" International Organization, 46/2:391-425.

Wendt, A. (1995) “Constructing International Politics", International Security, 20/1:71-81.

Wendt, A. (1999) Social Theory of International Politics, Cambridge: Cambridge University Press.

White, B. (1989) "Analysing Foreign Policy: Problems and Approaches", in Clarke, M. and B. White (eds.), Understanding Foreign Policy: The Foreign Policy System Approach, Hants: Edward Elgar.

Wurfel, D. and B. Burton (1990) "Introduction: A Foreign Policy Framework for South-east Asian States", in Wurfel, D. and B. Burton (eds.), The Political Economy of Foreign Policy in Southeast Asia, New York: St. Martin's Press.

Zakaria, F. (1998) From Wealth to Power: The Unusual Origins of America's World Role, Princeton: Princeton University Press. 